\title{
Pilot Study on the Utility of Circulating HER2/Neu Levels in the Serum of Breast Cancer Patients
}

\author{
SARAH MORGAN ${ }^{1,2}$, YUTAKA AMEMIYA ${ }^{1,2}$, ELZBIETA SLODKOWSKA ${ }^{1,2}$, FANG-I LU $^{1,2}$, \\ CARLOS PARRA-HERRAN ${ }^{1,2}$, SHARON NOFECH-MOZES ${ }^{1,2}$, MAUREEN TRUDEAU ${ }^{3}$, \\ EKATERINA OLKHOV-MITSEL ${ }^{1}$, ARUN SETH $^{1,2}$ and WEDAD M. HANNA ${ }^{1,2}$ \\ ${ }^{1}$ Department of Laboratory Medicine and Molecular Diagnostics, \\ Division of Anatomic Pathology, Sunnybrook Health Sciences Centre, Toronto, ON, Canada; \\ ${ }^{2}$ Department of Laboratory Medicine and Pathobiology, University of Toronto, Toronto, ON, Canada; \\ ${ }^{3}$ Department of Medical Oncology, Odette Cancer Centre, \\ Sunnybrook Health Sciences Centre, Toronto, ON, Canada
}

\begin{abstract}
Background/Aim: Accurate and timely assessment of the human epidermal growth factor receptor 2 (HER2/neu) overexpression is pivotal for the identification of breast cancer (BC) patients that could benefit from HER2-targeted therapy. Currently approved tissue-based HER2 assays (tHER2) are limited to testing HER2 status on tumor samples obtained at a few points in time during the course of the disease. Herein, we assessed serum HER2 (sHER2) status longitudinally in 81 serial samples prospectively collected from 43 consenting patients pre-and post-therapy to revisit the idea of serum testing in the follow-up of BC patients. Patients and Methods: The cohort included 11 patients with early $B C$ (EBC), 17 with locally advanced $B C(L A B C)$, and 15 with metastatic $B C$ (MBC). SHER2 concentrations were measured using a quantitative ELISA-based technique, using $15 \mathrm{ng} / \mathrm{ml}$ as the cutoff for positivity. Results: At baseline, sHER2 was negative in all EBC patients while positive in $1 \mathrm{LABC}$ and $5 \mathrm{MBC}$ patients. Sixteen $B C$ patients (10 LABC, $1 \mathrm{EBC}$, and $5 \mathrm{MBC}$ ) were tHER 2 positive. sHER2 and tHER2 results were discordant in 14 patients. Among the 16 tHER2 positive patients, 9 LABC, 1 $E B C$ and $2 M B C$ patients were sHER 2 negative. Conversely, 2 $M B C$ patients were sHER2 positive, despite being tHER2 negative. A rise or drop of SHER2 by $>20 \%$ correlated with
\end{abstract}

This article is freely accessible online.

Correspondence: Dr. Wedad M. Hanna, Division of Anatomic Pathology, Sunnybrook Health Sciences Centre, Room E4-32, 2075 Bayview Ave, Toronto, ON, Canada M4N 3M5. Tel: +14164806100 Ext: 3565, Fax: +1 4164804271, e-mail: wedad.hanna@ sunnybrook.ca ORCID: https://orcid.org/0000-0001-9191-3937

Key Words: HER2/Neu, breast cancer, extracellular domain, serum HER2, HER2-targeted therapy. disease progression or pathological response to therapy, respectively. Conclusion: The study demonstrated the technical validity and feasibility of the sHER 2 assay. Findings suggest that post initial tissue diagnosis (tHER2), sHER2 assay may supplement subsequent tissue tests to monitor disease status and response to therapy. Further studies to assess the role of HER2 targeted therapies in sHER-positiveltHER2-negative cases upon disease progression are warranted.

Gene amplification and overexpression of human epidermal growth factor receptor 2 (HER2/neu), detected in $\sim 15-20 \%$ of breast cancer (BC), is a significant prognostic and predictive marker of the disease $(1,2)$. HER2 overexpression has been associated with disease aggressiveness, poor prognosis, and survival benefit from HER2-targeted therapy (3-5). The standard diagnostic modalities to determine tissue HER2 (tHER2) status, including immunohistochemistry (IHC) and in situ hybridization (ISH), have become a mandatory test in all BC patients at the time of diagnosis (6$8)$. However, these tissue-based assays are affected by tumor discrepancy, testing accuracy, reproducibility and subjectivity in result interpretation (9-11). Although rare, heterogeneity in tHER 2 expression between primary tumor and metastases requires repeated biopsy to determine tHER2 status during disease progression $(12,13)$. Acquisition of tumor tissue is invasive and difficult to perform for certain disease sites. This underscores the unmet clinical need for an alternative method for accurate, real-time monitoring of HER2 status in a non-invasive manner to augment tissue-based information and guide BC therapeutic decision making in the neoadjuvant, adjuvant, and metastatic disease settings.

BC patients would greatly benefit from a blood test that could provide a real time assessment of circulating biomarkers, including circulating tumor cells, exosomes, cellfree tumor nucleic acid and proteins shed into the blood. Such 


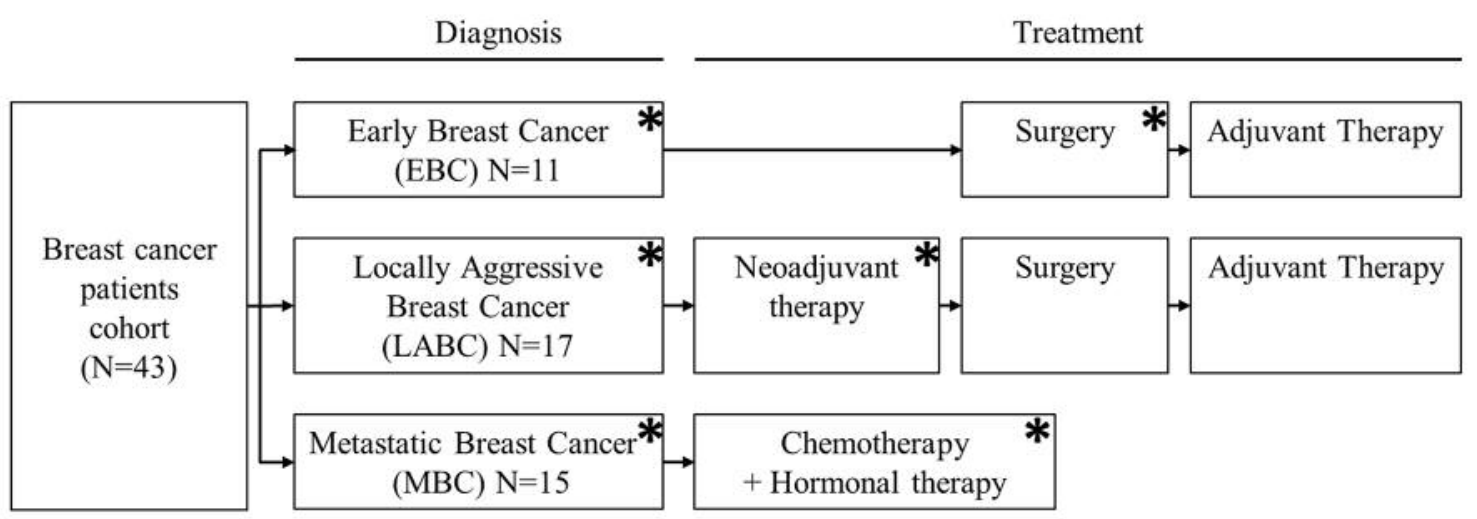

* Sample collection, samples were obtained twice from each patient

Figure 1. Study design .

a blood test termed "liquid biopsy" is minimally invasive and can be performed longitudinally to allow real-time monitoring of cells, nucleic acid and/or proteins derived from the primary tumor as well as metastatic sites (14). Thus, liquid biopsies can provide important information on tumor burden and biological properties. Recent advances in technology have led to novel potential applications of liquid biopsies for patient management and prognosis in the era of precision medicine. These potential applications include selection of targeted therapies, prediction and monitoring of treatment response, identifying therapeutic resistance mechanisms and early detection of disease relapse and/or metastasis $(15,16)$.

In light of this, one particularly attractive approach to HER2 testing is a serum-based assay for the HER2 extracellular domain (ECD) (17-19). The serum HER2 ECD (sHER2) is shed by BC tumor cells into the circulation via proteolytic cleavage by matrix metalloproteases and may be detected in the serum of patients with primary and metastatic disease (20). Detection of sHER2 by enzyme-linked immunosorbent assay (ELISA) using a monoclonal antibody directed against HER2 ECD has been reported as a potentially promising tool for real-time monitoring of HER2 status (2123). Furthermore, it has been shown that a subset (1.3-42.0\%) of tHER2-negative patients exhibit elevated sHER2, representing an additional subgroup of $\mathrm{BC}$ patients that might benefit from HER2-targeted therapies, although this has not been examined in a large randomized clinical trial $(24,25)$. Despite these reports, the utilization of sHER2 ELISA in the clinical setting has been hindered by inconsistent findings. First, strong correlation between sHER 2 and tHER 2 status has been reported in some studies, while others found poor correlation (22). Secondly, high pre-surgical sHER2 was observed to be strongly linked to worse prognosis in several studies, whereas baseline sHER2 levels have also been found to be prognostic of better outcome (26). Lastly, a few studies have discovered that reduction in sHER2 is indicative of response to trastuzumab (with or without chemotherapy). However, various publications report different minimal percentage decrease in baseline sHER2 (e.g. 9\%, 20\%, 55\%) over diverse periods of time, ranging from days to weeks posttreatment, as necessary to reach clinically significant improvement in prediction of treatment outcome $(27,28)$ Conversely, other studies report no decline in sHER 2 in patients responsive to Trastuzumab-based therapy (22). Possible explanations for these inconsistencies may include discrepancies in methodology and lack of adherence to the international guidelines for tumor marker research. In this regard, additional studies are needed to consolidate the utility of sHER2 ELISA in the management of BC.

The purpose of this prospective study was to assess the technical feasibility and clinical utility of a standardized sHER2 ELISA kit for longitudinal monitoring of sHER2 levels in early, locally advanced and metastatic BC patients. A secondary goal was to examine the association between sHER2 and tHER2 status in correlation with disease progression and response to therapy.

\section{Patients and Methods}

Study population. Following approval for the study from the ethics committee and with an informed consent, serum samples were prospectively collected from BC patients at Sunnybrook Health Science Centre between 2015 and 2017. We targeted 3 groups of BC patients, collecting 2 samples from each patient (Figure 1). The first group included early BC patients (EBC), from whom blood was collected before and after surgery. The second group consisted of locally advanced $\mathrm{BC}$ (LABC) patients, from whom blood was 
Table I. Clinicopathological characteristics of the study cohort.

\begin{tabular}{|c|c|c|c|}
\hline & $\begin{array}{c}\text { Early breast } \\
\text { cancer }(\mathrm{EBC}), \\
\mathrm{n}(\%)\end{array}$ & $\begin{array}{c}\text { Locally aggressive } \\
\text { breast cancer } \\
(\text { LABC }), \mathrm{n}(\%)\end{array}$ & $\begin{array}{c}\text { Metastatic breast } \\
\text { cancer (MBC), } \\
\text { n (\%) }\end{array}$ \\
\hline Total & 11 & 17 & 15 \\
\hline \multicolumn{4}{|l|}{ Histologic subtype } \\
\hline Invasive ductal carcinoma (IDC) & $8(18.6 \%)$ & $15(34.9 \%)$ & $10(23.3 \%)$ \\
\hline Invasive lobular carcinoma (ILC) carcinoma (ILC) & $1(2.3 \%)$ & $2(4.7 \%)$ & $2(4.7 \%)$ \\
\hline IDC/ILC & $1(2.3 \%)$ & 0 & $1(2.3 \%)$ \\
\hline Mucinous carcinoma & $1(2.3 \%)$ & 0 & 0 \\
\hline Invasive carcinoma, NOS & 0 & 0 & $2(4.7 \%)$ \\
\hline \multicolumn{4}{|l|}{ Tumor grade } \\
\hline I & $3(7.0 \%)$ & $2(4.7 \%)$ & $1(2.3 \%)$ \\
\hline II & $6(14.0 \%)$ & $11(25.6 \%)$ & $4(9.3 \%)$ \\
\hline III & $2(4.7 \%)$ & $3(7.0 \%)$ & $6(14.0 \%)$ \\
\hline Unknown & 0 & $1(2.3 \%)$ & $4(9.3 \%)$ \\
\hline \multicolumn{4}{|l|}{ Lymphovascular invasion (LVI) } \\
\hline Negative & $9(20.9 \%)$ & $14(32.6 \%)$ & $8(18.6 \%)$ \\
\hline Positive & $2(4.7 \%)$ & $3(7.0 \%)$ & $4(9.3 \%)$ \\
\hline Unknown & 0 & 0 & $3(7.0 \%)$ \\
\hline \multicolumn{4}{|l|}{ Axillary lymph node involvement } \\
\hline Negative & $9(20.9 \%)$ & $5(11.6 \%)$ & $2(4.7 \%)$ \\
\hline Positive & $2(4.7 \%)$ & $11(25.6 \%)$ & $12(27.9 \%)$ \\
\hline Unknown & 0 & $1(2.3 \%)$ & $1(2.3 \%)$ \\
\hline \multicolumn{4}{|l|}{ tHER2 } \\
\hline Negative & $10(23.3 \%)$ & $7(16.3 \%)$ & $10(23.3 \%)$ \\
\hline Positive & $1(2.3 \%)$ & $10(23.3 \%)$ & $5(11.6 \%)$ \\
\hline \multicolumn{4}{|l|}{ sHER2 } \\
\hline Negative & $13(30.2 \%)$ & $16(37.2 \%)$ & $11(25.6 \%)$ \\
\hline Positive & 0 & $1(2.3 \%)$ & $4(9.3 \%)$ \\
\hline \multicolumn{4}{|l|}{ Follow-up } \\
\hline Mean follow-up time (months)* & $7($ range $=1-16)$ & $9($ range $=4-17)$ & $10($ range $=3-27)$ \\
\hline Complete remission & $9(20.9 \%)$ & $16(37.2 \%)$ & 0 \\
\hline Stable/partial remission & $2(4.7 \%)$ & $1(2.3 \%)$ & $3(7.0 \%)$ \\
\hline Progression & 0 & 0 & $10(23.3 \%)$ \\
\hline Recurrence & 0 & 0 & 0 \\
\hline Death & 0 & 0 & $2(4.7 \%)$ \\
\hline
\end{tabular}

*Follow-up time was defined from the date of the first blood sample drawn for the study to date of last follow up or date of disease progression or death of disease.

collected before and after neoadjuvant chemotherapy. The third group was metastatic BC (MBC) patients from whom 2 blood samples were collected 6 months apart regardless of systemic therapy cycles. Clinicopathological characteristics were retrieved from electronic medical records (Table I). Both tHER2 positive and negative patients were included in the study. Informed consent was obtained from all individual participants included in the study. All procedures performed involving human participants were in accordance with the ethical standards of the institutional and/or national research committee and with the 1964 Helsinki declaration and its later amendments or comparable ethical standards. The study was reviewed and approved by Sunnybrook Health Sciences Centre research ethics board.

Serum specimen collection and processing. Blood samples $(6 \mathrm{ml})$ were taken in plain vacutainer serum tubes under sterile conditions and were allowed to clot for 0.5-1 h. Samples were then centrifuged at $1500 \mathrm{~g}$ for $15 \mathrm{~min}$. Serum was aliquoted in amber aliquot tubes and stored at $-80^{\circ} \mathrm{C}$.
Enzyme-linked immunosorbent assay (ELISA). The HER2/neu ELISA IVD kit (Nuclea Diagnostic Laboratories LLC, MA, USA) was used for the quantitative estimation of soluble p105 (molecular weight $105 \mathrm{kDa}$ ) ECD of the HER2 protein in serum. All procedures were performed according to manufacturer's recommendations. Standard curves were generated using 6 standards of recombinant human HER2 ECD with known concentrations of 0.0, 2.5, 7.5, 15.0, 25.0 and $35.0 \mathrm{ng} / \mathrm{ml}$. The serum specimens were diluted to $1: 50$ with the sample diluent provided in the kit. A dilution of 1:100 and/or 1:200 was needed only if the absorbance values exceeded the range of the standard curve. For monitoring quality of the assay, three different concentrations of HER-2/neu ELISA controls were also included on every microtiter plate. The standards, specimens and controls $(100 \mu \mathrm{l}$ per well) were added to the wells of microtiter plate in duplicate and incubated for $3 \mathrm{~h}$ at $37^{\circ} \mathrm{C}$. The plate was then washed six times with $300 \mu$ l of plate wash buffer $(1 \times)$ using automated plate washer equipment (TECAN Columbus Pro, TECAN U.S. Inc, Morrisville, NC, USA). After washing, the 
detector antibody $(100 \mu \mathrm{l}$ per well) was added and incubated for 1 $\mathrm{h}$ at $37^{\circ} \mathrm{C}$, then washed 6 times with $300 \mu \mathrm{l}$ of plate wash buffer.

The conjugate concentrate was diluted 1:50 with conjugate diluent, added to the plate $(100 \mu \mathrm{l}$ per well $)$ and incubated for 30 min at room temperature, then washed 6 times with $300 \mu l$ of plate wash buffer. Working substrate was added to each well (100 $\mu$ l per well) and incubated in the dark for $45 \mathrm{~min}$ at room temperature. The reaction was interrupted by adding $100 \mu$ of stop solution. The absorbance of each well was determined at $492 \mathrm{~nm}$ by a microtiter plate reader (TECAN Sunrise, TECAN U.S. Inc).

Data analysis. Controls and standard curves were inspected to confirm test performance prior to data analysis. Mean absorbance values from duplicate wells for each of the 6 different standards were used to generate a standard curve, which was used to determine HER2/neu protein concentration (y) for each sample by inserting the specimen's absorbance value (x). Samples with values $>15 \mathrm{ng} / \mathrm{ml}$ were considered positive as per manufacturer's instructions.

Statistical analysis. Pearson $\chi^{2}$ test was performed to assess correlation among sHER2, tHER2, clinicopathological variables and response to treatment. Fisher exact method was used when spreadsheet cell counts were $<5$. All statistical analyses were twosided and conducted using IBM SPSS Statistics version 24 (IBM Corporation, New York, NY, USA). All $p$-values $<0.05$ were considered statistically significant. Data are presented as mean \pm standard deviation (SD).

\section{Results}

Patient characteristics. Forty-three BC patients were prospectively enrolled to the pilot study (Figure 1); 11 EBC; $17 \mathrm{LABC}$; and $15 \mathrm{MBC}$. Clinicopathological characteristics by groups are outlined in Table I. Among the $15 \mathrm{MBC}$ patients, the metastatic sites included bone (13/15), liver (10/15), lung (7/15), and brain (4/15); Six out of fifteen patients $(6 / 15)$ had metastases at other sites. The majority of patients $(13 / 15)$ had at least two metastatic sites.

Evaluation of tissue and serum HER2 in EBC. Among the 11 EBC patients, 1 was tHER2 positive (Table II). sHER2 was negative in all EBC patients at baseline and at 6-month follow up. The tHER2 positive patient was sHER2 negative and had complete disease remission on-follow up. Mean preand post-therapy sHER2 levels were $10.1 \pm 1.9 \mathrm{ng} / \mathrm{ml}$ and $9.0 \pm 2.0 \mathrm{ng} / \mathrm{ml}$, respectively (Table II).

Tissue and serum HER2 status in LABC. Within the context of LABC, 10/17 patients were tHER2 positive (Table II). Mean pre- and post- therapy sHER2 levels were $11.4 \pm 5.9 \mathrm{ng} / \mathrm{ml}$, and $8.5 \pm 2.0 \mathrm{ng} / \mathrm{ml}$, respectively. One tHER2-positive LABC patient was also sHER2-positive pre-therapy. This patient was found to have inflammatory BC with nodal involvement. Post-therapy, sHER2 level showed an $82.0 \%$ drop with a value below the cutoff, which correlated with complete pathologic response to therapy (Table III). The 9 remaining tHER2+/sHER2- LABC
Table II. Concordance between tissue and serum HER2 status

\begin{tabular}{|c|c|c|c|c|c|}
\hline \multicolumn{2}{|c|}{ HER2 status } & \multirow{2}{*}{$\begin{array}{c}\text { EBC } \\
(\mathrm{N}=11)\end{array}$} & \multirow{2}{*}{$\begin{array}{l}\text { LABC } \\
(\mathrm{N}=17)\end{array}$} & \multirow{2}{*}{$\begin{array}{c}\text { MBC } \\
(\mathrm{N}=15)\end{array}$} & \multirow{2}{*}{$\begin{array}{c}\text { Total } \\
(\mathrm{N}=43)\end{array}$} \\
\hline Tissue & Serum & & & & \\
\hline \multirow[t]{2}{*}{-} & - & 10 & 7 & 8 & 25 \\
\hline & + & 0 & 0 & 2 & 2 \\
\hline \multirow[t]{2}{*}{+} & - & 1 & 9 & 2 & 12 \\
\hline & + & 0 & 1 & 3 & 4 \\
\hline
\end{tabular}

EBC, Early breast cancer; LABC, locally aggressive breast cancer; $\mathrm{MBC}$, metastatic breast cancer.

patients experienced complete pathologic response to neoadjuvant systemic therapy.

Prevalence of tissue and serum HER2 in MBC. Of the $15 \mathrm{MBC}$ patients in the study, 5 were tHER2 positive (Table II). Mean sHER2 levels in the baseline and second samples were $17.6 \pm 14.7 \mathrm{ng} / \mathrm{ml}$ and $22.4 \pm 24.1 \mathrm{ng} / \mathrm{ml}$, respectively. sHER2 positivity was detected in the baseline sample of $4 \mathrm{MBC}$ patients (Table III). Among these, 3 were positive for both tHER2 and sHER2 while 1 was tHER2 negative/sHER2 positive. The latter patient had diffuse liver metastasis with impaired liver function and progressed on several lines of chemotherapy. Furthermore, the 2 tHER2 positive/sHER2 negative MBC patients showed disease progression (Table I \& II).

In second samples, sHER2 positivity was detected in $4 \mathrm{MBC}$ patients. Of these, 1 patient had a $54.1 \%$ rise in sHER2 levels from a negative baseline sample to a positive second sample (Table III). The remaining $3 \mathrm{MBC}$ patients were positive for sHER2 in both samples and also demonstrated a rise (from $1.2 \%$ to $65.5 \%$ ) in sHER2 levels from the baseline sample. All MBC patients positive for sHER2 in the second serum sample showed disease progression on numerous lines of chemotherapy, one of whom died of disease 26 months post diagnosis (mean follow-up time 10 months, range 3-27 months). Of note, 1 MBC patient who was initially positive for sHER2 and became negative post-chemotherapy plus targeted HER2 therapy demonstrated a $64.9 \%$ decrease in sHER2 levels, which correlated with partial disease remission (Table III).

\section{Discussion}

The implemtation of sHER2 testing in routine management of patients is hampered by lack of consistent findings regarding its concordance with tHER2 testing and lack of data from randomized clinical trials regarding its ability to predict response to HER2-targeted therapies in patients with negative tHER2. This is attributed to lack of standardisation in sHER2 assessment, different assay techniques, study designs and use of different cut-offs for sHER2 positivity. In 
Table III. Characteristics of patients positive for serum HER2.

\begin{tabular}{|c|c|c|c|c|c|c|c|c|c|c|c|}
\hline \multicolumn{4}{|c|}{ HER2 status } & \multirow[b]{2}{*}{ Disease } & \multirow[b]{2}{*}{$\begin{array}{l}\text { Histologic } \\
\text { presentation }\end{array}$} & \multirow[b]{2}{*}{$\begin{array}{c}\text { Grade } \\
\text { subtype }\end{array}$} & \multirow[b]{2}{*}{ LVI } & \multirow[b]{2}{*}{$\begin{array}{c}\text { Nodal } \\
\text { involvement }\end{array}$} & \multirow[b]{2}{*}{$\begin{array}{c}\text { ER } \\
\text { status }\end{array}$} & \multirow[b]{2}{*}{$\begin{array}{l}\text { PR } \\
\text { status }\end{array}$} & \multirow[b]{2}{*}{ Outcome } \\
\hline & $\begin{array}{c}\text { Serum } \\
\text { sample } \\
1(\mathrm{ng} / \mathrm{ml})\end{array}$ & $\begin{array}{c}\text { Serum } \\
\text { sample } \\
2(\mathrm{ng} / \mathrm{ml})\end{array}$ & Tissue & & & & & & & & \\
\hline 1 & 41.4 & 68.5 & + & MBC & IDC & III & - & - & + & - & Died of disease \\
\hline 2 & 10.9 & 16.8 & - & $\mathrm{MBC}$ & IDC & III & - & + & + & & Disease progression \\
\hline 3 & 16.6 & 16.8 & - & $\mathrm{MBC}$ & IDC/ILC & II & - & + & + & + & Disease progression \\
\hline 4 & 57.6 & 78.4 & + & $\mathrm{MBC}$ & Invasive carcinoma & & - & + & - & - & Disease progression \\
\hline 5 & 33.9 & 11.9 & + & $\mathrm{MBC}$ & IDC & III & - & + & + & + & Partial response/Stable disease \\
\hline 6 & 32.7 & 5.9 & + & LABC & IDC & II & - & + & + & - & Complete pathological response \\
\hline
\end{tabular}

MBC, Metastatic breast cancer; LABC, locally aggressive breast cancer; IDC, invasive ductal carcinoma; ILC, invasive lobular carcinoma; LVI, lymphovascular invasion; ER, estrogen receptor; PR, progesterone receptor

this setting, in the current study we used a standardized sHER2 ELISA kit and a cut-off of $15 \mathrm{ng} / \mathrm{ml}$, which was recommended by the manufacturer and used in several other studies $(22,24,29)$. This cut-off was established in a study by Wang et al. (30), where the prognostic value of sHER2 ECD, at a cut off of $15 \mathrm{ng} / \mathrm{ml}$, was demonstrated using univariate $(\mathrm{HR}=1.664, p<0.0001)$ and multivariate analysis $(\mathrm{HR}=1.547, \quad p=0.011)$. Kaplan-Meier survival curves revealed that patients with $\mathrm{SHER} 2>15 \mathrm{ng} / \mathrm{ml}$ had shorter progression-free survival $(p<0.0001)$.

A greater proportion of sHER2 positivity was identified in the metastatic setting (5/15 of MBC patients, vs. 0/11 of EBC and 1/17 LABC patients), irrespective of tHER2 status at diagnosis. This finding is consistent with results from prior studies. Molina et al. (31) have showed that sHER2 concentrations in patients with advanced disease were related to the site of recurrence, with significantly higher values in metastatic patients compared to those with loco-regional recurrence. Similarly, they stated that over $40 \%$ of patients with MBC demonstrated elevated sHER2 levels, whereas only $14.3 \%$ of patients with stage I or II disease demonstrated elevated sHER2 levels $(29,32)$.

sHER2 positivity also correlated with burden of disease. Of the 5 tHER2 positive MBC patients, 2 were sHER2 negative; 1 of whom was newly diagnosed with a small liver metastasis, and 1 with stable bone and liver metastases on chemotherapy. Furthermore, sHER 2 negative status was seen in 9/10 tHER2 positive LABC patients and 1/1 tHER2 positive EBC patient, which emphasizes that patients with low tumor burden are less likely to be sHER2 positive.

Although the prognostic value of the initial sHER 2 could not be evaluated in the current study, we did find that a larger subset of sHER 2 positive patients showed disease progression (4/6) compared to sHER2 negative patients (8/37). In particular, 1 tHER 2 positive patient showed a very high baseline sHER 2 concentration $(57.6 \mathrm{ng} / \mathrm{ml})$ and even higher subsequent sHER2 level $(78.4 \mathrm{ng} / \mathrm{ml})$. sHER2 results in this patient were synchronous with disease progression on up to five lines of chemotherapy. This is consistent with studies that have shown associations between raised concentrations of sHER2 and poor prognosis $(29,30,32,33)$. Others have suggested that the prognostic value of sHER2 is limited to advanced stage BC patients only $(27,28,34)$.

The findings also demonstrate that changes in sHER2 level may correlate with treatment response. All 4 patients with consistently positive sHER2 levels post-treatment had poor response to treatment with disease progression, whereas the 2 patients with negative sHER2 seroconversion post-treatment had partial or complete pathological response to HER2targeted therapy. These findings are similar to two large prospective studies, in which patients who did not achieve $\geq 20 \%$ decline in sHER2 levels had less response to Trastuzumab-based therapy $(31,35)$. Interestingly, two other large studies demonstrated that tHER2-positive patients with $\geq 20 \%$ decrease in sHER2 achieved therapeutic success, even if therapy was not HER2-targeted $(29,36,37)$. Our study adds further evidence to support the published cut-off of $20 \%$ to define significant decrease in sHER2, as the two patients in our study with partial or complete response to therapy had a $64.9 \%$ and an $82 \%$ drop in sHER2, respectively.

Previous studies showed that baseline sHER2 positivity at diagnosis lacked predictive value for response to HER2targeted therapy. This was demonstrated in a study of 296 LABC and MBC patients treated with Trastuzumab-based therapies, of which 205 (69\%) had sHER2 >15 ng/ml (26). No significant associations were found between baseline sHER2 and tumour response, as $48 \%$ of patients with $<15 \mathrm{ng} / \mathrm{ml}$ baseline sHER2 responded to the treatment regimen vs. $52 \%$ of those with $>15 \mathrm{ng} / \mathrm{ml}$ baseline sHER2. Similar result was seen in patients with Trastuzumab monotherapy (30). 


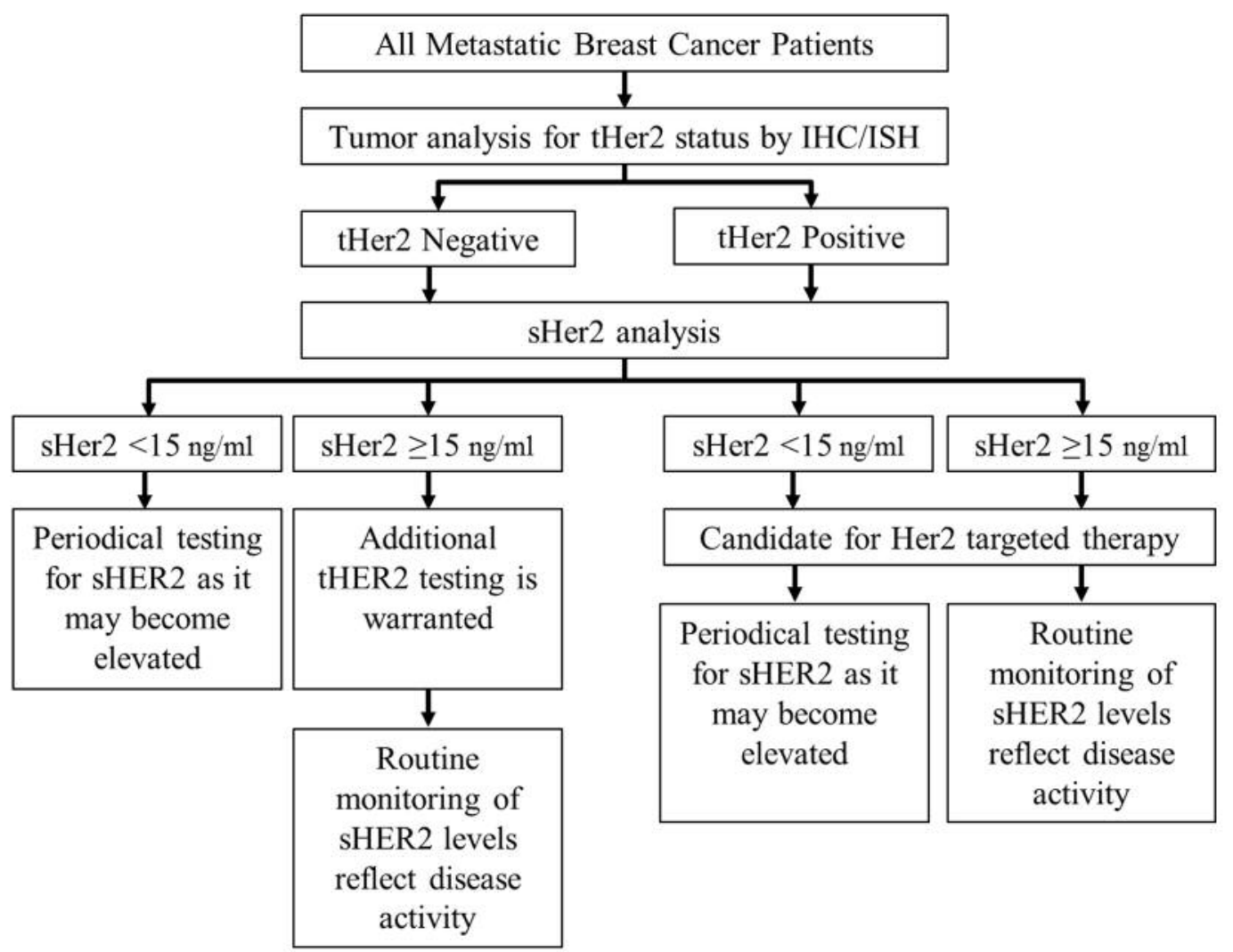

Figure 2. Proposed algorithm to HER2 testing utilizing both serum and tissue HER2/neu assays in breast cancer patients.

Some studies have proposed to use sHER2 concentration as an alternative to histological determination of tHER2 status $(26,29,38)$. Our data did not support this notion as 14 of 43 patients in the present study had discordant tHER2 and sHER2 status. Similarly, several other groups have failed to reliably correlate tHER2 status to sHER2 levels $(26,39,40)$. The discordance can be indicative of different biological subgroups of breast tumors with various levels of HER2 cleavage and shedding irrespective of tHER2 status. Alternatively, it could be attributed to several other factors. First, heterogeneity in primary and metastatic BC could result in small areas of HER2 positive cancer that is not assessed on tissue analysis, but sheds detectable sHER2 into the circulation. Second, extensive liver metastasis may impede its function and ability to degrade normally shed sHER2 (41, 42). Indeed, one patient in our study with tHER2 negative/sHER2 positive profile had extensive liver metastasis. Hence, sHER2 and tHER2 are not interchangeable and should be used as complementary markers.

In conclusion, the results of this proof-of-concept study support the potential use of sHER2 as a tool complementary to tHER2 for monitoring BC progression, particularly in the advanced and metastatic settings. A suggested algorithm is shown in Figure 2. Although sHER2 positivity was associated with response to therapy, a predictive value could not be concluded from this study, due to small sample size and data requirement beyond the main objective of the study. Due to lack of correlation between sHER2 and tHER2 results, it is recommended to use clinical parameters and tissue HER2 testing according to the national guidelines when making decisions about initiation, continuation, and discontinuation of HER2-targeted treatments.

\section{Conflicts of Interest}

The Authors declare that they have no competing interests.

\section{Authors' Contributions}

SM: Sample collection, literature search and design of the work; YA: performed experiments and interpretation of data; ES, FL, CPH, SNM: identification and assessment of patient cohort; MT: research concept and access to patients; EOM: drafting the work; AS: revising manuscript critically for intellectual content; WMH: conception of the work. 


\section{Funding}

The study was funded by the academic fund of the Division of Anatomic Pathology, Sunnybrook Health Sciences Centre.

\section{Data Availability Statement}

The datasets generated and/or analyzed for the current study are not publicly available, because of the proprietary information contained within, but are available from the corresponding Author on reasonable request.

\section{References}

1 Slamon DJ, Clark GM, Wong SG, Levin WJ, Ullrich A and McGuire WL: Human breast cancer: correlation of relapse and survival with amplification of the HER-2/neu oncogene. Science 235: 177-182, 1987. PMID: 3798106. DOI: 10.1126/science. 3798106

2 Owens MA, Horten BC and Da Silva MM: HER2 Amplification ratios by fluorescence in situ hybridization and correlation with immunohistochemistry in a cohort of 6556 breast cancer tissues. Clin Breast Cancer 5: 63-69, 2004. PMID: 15140287. DOI: 10.3816/CBC.2004.n.011

3 Slamon DJ, Leyland-Jones B, Shak S, Fuchs H, Paton V, Bajamonde A, Fleming T, Eiermann W, Wolter J, Pegram M, Baselga $J$ and Norton L: Use of chemotherapy plus a monoclonal antibody against HER2 for metastatic breast cancer that overexpresses HER2. N Engl J Med 344: 783-792, 2001. PMID: 11248153. DOI: 10.1056/NEJM200103153441101

4 Tafe LJ and Tsongalis GJ: The human epidermal growth factor receptor 2 (HER2). Clin Chem Lab Med 50: 23-30, 2011. PMID: 21919545. DOI: $10.1515 / \mathrm{cclm} .2011 .707$

5 Goldhirsch A, Winer EP, Coates AS, Gelber RD, Piccart-Gebhart M, Thürlimann B, Senn H-J, Albain KS, André F, Bergh J, Bonnefoi $\mathrm{H}$, Bretel-Morales $\mathrm{D}$, Burstein $\mathrm{H}$, Cardoso $\mathrm{F}$, Castiglione-Gertsch M, Coates AS, Colleoni M, Costa A, Curigliano G, Davidson NE, Di Leo A, Ejlertsen B, Forbes JF, Gelber RD, Gnant M, Goldhirsch A, Goodwin P, Goss PE, Harris JR, Hayes DF, Hudis CA, Ingle JN, Jassem J, Jiang Z, Karlsson P, Loibl S, Morrow M, Namer M, Kent Osborne C, Partridge AH, Penault-Llorca F, Perou CM, Piccart-Gebhart MJ, Pritchard KI, Rutgers EJT, Sedlmayer F, Semiglazov V, Shao Z-M, Smith I, Thürlimann B, Toi M, Tutt A, Untch M, Viale G, Watanabe T, Wilcken N, Winer EP and Wood WC: Personalizing the treatment of women with early breast cancer: highlights of the St Gallen International Expert Consensus on the Primary Therapy of Early Breast Cancer 2013. Ann Oncol 24: 2206-2223, 2013. PMID: 23917950. DOI: 10.1093/ annonc/mdt303

6 Wolff AC, Hammond MEH, Hicks DG, Dowsett M, McShane LM, Allison KH, Allred DC, Bartlett JMS, Bilous M, Fitzgibbons P, Hanna W, Jenkins RB, Mangu PB, Paik S, Perez EA, Press MF, Spears PA, Vance GH, Viale G and Hayes DF: Recommendations for human epidermal growth factor receptor 2 testing in breast cancer: American Society of Clinical Oncology/College of American Pathologists clinical practice guideline update. J Clin Oncol 31: 3997-4013, 2013. PMID: 24101045. DOI: $10.1200 / J C O .2013 .50 .9984$
7 Hanna WM, Barnes PJ, Chang MC, Gilks CB, Magliocco AM, Rees H, Quenneville L, Robertson SJ, SenGupta SK and Nofech-Mozes S: Human epidermal growth factor receptor 2 testing in primary breast cancer in the era of standardized testing: A Canadian prospective study. J Clin Oncol 32: 39673973, 2014. PMID: 25385731. DOI: 10.1200/JCO.2014.55.6092

8 Hanna WM, Slodkowska E, Lu F-I, Nafisi H and Nofech-Mozes $\mathrm{S}$ : Comparative analysis of human epidermal growth factor receptor 2 testing in breast cancer according to 2007 and 2013 American Society of Clinical Oncology/College of American Pathologists Guideline Recommendations. J Clin Oncol 35: 30393045, 2017. PMID: 28445098. DOI: 10.1200/JCO.2016. 70.5319

9 Perez EA, Suman VJ, Davidson NE, Martino S, Kaufman PA, Lingle WL, Flynn PJ, Ingle JN, Visscher D and Jenkins RB: HER2 testing by local, central, and reference laboratories in specimens from the North Central Cancer Treatment Group N9831 Intergroup Adjuvant Trial. J Clin Oncol 24: 3032-3038, 2006. PMID: 16809727. DOI: 10.1200/JCO.2005.03.4744

10 Sauter G, Lee J, Bartlett JMS, Slamon DJ and Press MF: Guidelines for human epidermal growth factor receptor 2 testing: Biologic and methodologic considerations. J Clin Oncol 27: 1323-1333, 2009. PMID: 19204209. DOI: 10.1200/JCO. 2007.14.8197

11 Sapino A, Goia M, Recupero D and Marchiò C: Current Challenges for HER2 Testing in Diagnostic Pathology: State of the Art and Controversial Issues. Front Oncol 3, 2013. PMID: 23734345. DOI: 10.3389/fonc.2013.00129

12 Niikura N, Liu J, Hayashi N, Mittendorf EA, Gong Y, Palla SL, Tokuda Y, Gonzalez-Angulo AM, Hortobagyi GN and Ueno NT: Loss of human epidermal growth factor receptor 2 (HER2) expression in metastatic sites of HER2-overexpressing primary breast tumors. J Clin Oncol 30: 593-599, 2012. PMID: 22124109. DOI: $10.1200 /$ JCO.2010.33.8889

13 Wilking U, Karlsson E, Skoog L, Hatschek T, Lidbrink E, Elmberger G, Johansson H, Lindström L and Bergh J: HER2 status in a population-derived breast cancer cohort: discordances during tumor progression. Breast Cancer Res Treat 125: 553561, 2011. PMID: 20628810. DOI: 10.1007/s10549-010-1029-2

14 Wan JCM, Massie C, Garcia-Corbacho J, Mouliere F, Brenton JD, Caldas C, Pacey S, Baird R and Rosenfeld N: Liquid biopsies come of age: towards implementation of circulating tumour DNA. Nat Rev Cancer 17: 223-238, 2017. PMID: 28233803. DOI: $10.1038 /$ nrc.2017.7

15 Scripcariu V, Scripcariu D-V, Filip B, Gavrilescu M-M, Muşină A-M and Volovăţ C: "Liquid biopsy" - Is it a feasible option in colorectal cancer? Chirurgia 114: 162, 2019. PMID: 31060647. DOI: $10.21614 /$ chirurgia.114.2.162

16 Muluhngwi P, Valdes R, Fernandez-Botran R, Burton E, Williams B and Linder MW: Cell-free DNA diagnostics: Current and emerging applications in oncology. Pharmacogenomics 20: 357-380, 2019. PMID: 30983510. DOI: 10.2217/pgs-2018-0174

17 Sias PE, Kotts CE, Vetterlein D, Shepard M and Wong WLT: ELISA for quantitation of the extracellular domain of p185HER2 in biological fluids. J Immunol Methods 132: 73-80, 1990. PMID:1975263. DOI: 10.1016/0022-1759(90)90400-P

18 Cook GB, Neaman IE, Goldblatt JL, Cambetas DR, Hussain M, Lüftner D, Yeung KK, Chan DW, Schwartz MK and Allard WJ: Clinical utility of serum HER-2/neu testing on the Bayer Immuno 1 automated system in breast cancer. Anticancer Res 21: 1465-1470, 2001. PMID: 11396233 
19 Carney WP: Potential clinical utility of serum HER-2/neu oncoprotein concentrations in patients with breast cancer. Clin Chem 49: 1579-1598, 2003. PMID: 14500583. DOI: 10.1373/ 49.10.1579

20 Codony-Servat J, Albanell J, Lopez-Talavera JC, Arribas J and Baselga $\mathrm{J}$ : Cleavage of the HER2 ectodomain is a pervanadateactivable process that is inhibited by the tissue inhibitor of metalloproteases-1 in breast cancer cells. Cancer Res 59: 11961201, 1999. PMID: 10096547.

21 McDermett E, Dully K, O’Higgins N, Fennelly J and Duffy' MJ: Enzyme-linked immunosorbent assay of c-erbB-2 oncoprotein in breast cancer. Clin Chem 38: 1471-147, 1992. PMID: 1353709.

22 Lam L, McAndrew N, Yee M, Fu T, Tchou JC and Zhang H: Challenges in the clinical utility of the serum test for HER2 ECD. Biochim Biophys Acta (BBA) - Reviews on Cancer 1826: 199208, 2012. PMID: 22521738. DOI: 10.1016/j.bbcan.2012.03.012

23 Leary AF, Hanna WM, van de Vijver MJ, Penault-Llorca F, Rüschoff J, Osamura RY, Bilous M and Dowsett M: Value and limitations of measuring HER-2 extracellular domain in the serum of breast cancer patients. J Clin Oncol 27: 1694-1705, 2009. PMID: 19255333. DOI: 10.1200/JCO.2008.17.3989

24 Tsé C, Gauchez A-S, Jacot W and Lamy P-J: HER2 shedding and serum HER2 extracellular domain: Biology and clinical utility in breast cancer. Cancer Treat Rev 38: 133-142, 2012. PMID:21549508. DOI: 10.1016/j.ctrv.2011.03.008

25 Ardavanis A, Kountourakis P, Kyriakou F, Malliou S, Mantzaris I, Garoufali A, Yiotis I, Scorilas A, Baziotis N and Rigatos G: Trastuzumab plus paclitaxel or docetaxel in HER-2negative/HER-2 ECD-positive anthracycline- and taxanerefractory advanced breast cancer. Oncologist 13: 361-369, 2008. PMID:18448549. DOI: 10.1634/theoncologist.2007-0207

26 Lennon S, Barton C, Banken L, Gianni L, Marty M, Baselga J and Leyland-Jones B: Utility of serum HER2 extracellular domain assessment in clinical decision making: Pooled analysis of four trials of trastuzumab in metastatic breast cancer. JClin Oncol 27: 1685-1693, 2009. PMID: 19255335. DOI: 10.1200/ JCO.2008.16.8351

27 Ali SM, Carney WP, Esteva FJ, Fornier M, Harris L, Köstler WJ, Lotz J-P, Luftner D, Pichon M-F and Lipton A: Serum HER-2/ neu and relative resistance to trastuzumab-based therapy in patients with metastatic breast cancer. Cancer 113: 1294-1301, 2008. PMID: 18661530. DOI: 10.1002/cncr.23689

28 Reix N, Malina C, Chenard M-P, Bellocq J-P, Delpous S, Molière S, Sevrin A, Neuberger K, Tomasetto C and Mathelin $\mathrm{C}$ : A prospective study to assess the clinical utility of serum HER2 extracellular domain in breast cancer with HER2 overexpression. Breast Cancer Res Treat 160: 249-259, 2016. PMID: 27709352. DOI: 10.1007/s10549-016-4000-z

29 Colomer R, Montero S, Lluch A, Ojeda B, Barnadas A, Casado A, Massutí B, Cortés-Funes H and Lloveras B: Circulating HER2 extracellular domain and resistance to chemotherapy in advanced breast cancer. Clin Cancer Res: an official journal of the American Association for Cancer Research 6: 2356-2362, 2000. PMID: 10873087.

30 Wang T, Zhou J, Zhang S, Bian L, Hu H, Xu C, Hao X, Liu B, Ye Q, Liu Y and Jiang Z: Meaningful interpretation of serum HER2 ECD levels requires clear patient clinical background, and serves several functions in the efficient management of breast cancer patients. Clin Chim Acta 458: 23-29, 2016. PMID: 27109901. DOI: $10.1016 /$ j.cca.2016.04.025
31 Molina R, Jo J, Filella X, Zanon G, Pahisa J, Muñoz M, Farrus B, Latre ML, Gimenez N, Hage M, Estape J and Ballesta AM: C-erbB-2 oncoprotein in the sera and tissue of patients with breast cancer. Utility in prognosis. Anticancer Res 16: 22952300, 1996. PMID: 8694559.

32 Krainer M, Brodowicz T, Zeillinger R, Wiltschke C, Scholten C, Seifert M, Kubista E and Zielinski CC: Tissue expression and serum levels of HER-2/neu in patients with breast cancer. Oncology 54: 475-481, 1997. PMID: 9394844. DOI: 10.1159/00 0227606

33 Leyland-Jones B and Smith BR: Serum HER2 testing in patients with HER2-positive breast cancer: the death knell tolls. Lancet Oncol 12: 286-295, 2011. PMID: 21376291. DOI: 10.1016/S14 70-2045(10)70297-7

34 Lipton A, Leitzel K, Ali SM, Carney W, Platek G, Steplewski K, Westlund R, Gagnon R, Martin A-M and Maltzman J: Human epidermal growth factor receptor 2 (HER2) extracellular domain levels are associated with progression-free survival in patients with HER2-positive metastatic breast cancer receiving lapatinib monotherapy: Serum HER2 Predicts Lapatinib Response. Cancer 117: 5013-5020, 2011. PMID: 21456017. DOI: 10.1002/cncr.26101

35 Krainer M, Brodowicz T, Zeillinger R, Wiltschke C, Scholten C, Seifert M, Kubista E and Zielinski CC: Tissue expression and serum levels of HER-2/neu in patients with breast cancer. Oncology 54: 475-481, 1997. PMID: 9394844. DOI: 10.1159/000227606

36 Kong S-Y: Serum HER-2 concentration in patients with primary breast cancer. J Clin Pathol 59: 373-736, 2006. PMID: 16461567. DOI: $10.1136 /$ jcp.2005.029603

37 Finn RS, Gagnon R, Di Leo A, Press MF, Arbushites M and Koehler M: Prognostic and predictive value of HER2 extracellular domain in metastatic breast cancer treated with lapatinib and paclitaxel in a randomized phase III study. J Clin Oncol 27: 55525558, 2009. PMID: 19858400. DOI: 10.1200/JCO.2008.21.1763

38 Christianson TA, Doherty JK, Lin YJ, Ramsey JEE, Holmes R, Keenan EJ and Clinton GM: NH2-terminally truncated HER2/neu protein: Relationship with shedding of the extracellular domain and with prognostic factors in breast cancer. Cancer Res 58: 5123-5129, 1998. PMID: 9823322.

39 Ross JS and Fletcher JA: The HER-2/neu oncogene in breast cancer: Prognostic factor, predictive factor, and target for therapy. Stem Cells 16: 413-428, 1998. PMID: 9831867. DOI: 10.1002/stem.160413

40 Vargas-Roig LM, Gago FE, Tello O, Martin de Civetta MT and Ciocca DR: c-erbB-2 (HER-2/neu) protein and drug resistance in breast cancer patients treated with induction chemotherapy. Int J Cancer 84: 129-134, 1999. PMID: 10096243. DOI: 10.1002/(SICI) 1097-0215(19990420)84:2<129::AID-IJC6>3.0.CO;2-4

41 Molina R, Jo J, Filella X, Bruix J, Castells A, Hague M and Ballesta AM: Serum levels of C-erbB-2 (HER-2/neu) in patients with malignant and non-malignant diseases. Tumour Biol 18: 188-196, 1997. PMID: 9143415. DOI: 10.1159/000218029

42 Ha J-H, Seong M-K, Kim E-K, Lee JK, Seol H, Lee JY, Byeon J, Sohn Y-J, Koh JS, Park I-C, Noh WC and Kim H-A: Serial serum HER2 measurements for the detection of breast cancer recurrence in HER2-positive patients. J Breast Cancer 17: 33, 2014. PMID: 24744795. DOI: 10.4048/jbc.2014.17.1.33.

Received July 10, 2019

Revised August 4, 2019 Accepted August 23, 2019 